\title{
Restriction endonuclease analysis of leukocyte mitochondrial DNA in Leber's optic atrophy
}

\author{
I J HOLT, D H MILLER, A E HARDING \\ From the University Department of Clinical Neurology, Institute of Neurology, London, UK
}

SUMMARY In order to test the hypothesis that Leber's optic atrophy may be caused by mutation of the mitochondrial $(\mathrm{mt})$ genome, restriction fragment length polymorphism in leukocyte mt DNA was studied in 16 patients with Leber's optic atrophy, 28 of their unaffected matrilineal relatives, and 35 normal control subjects. No differences in restriction fragment patterns were observed between affected and unaffected individuals in the same maternal line, and there was no evidence of major deletion of mt DNA in patients. This study provides no positive evidence of mitochondrial inheritance in Leber's optic atrophy but does not exclude it.

Leber's optic atrophy gives rise to acute or subacute bilateral visual loss, usually in young adult males. Initially the optic discs are swollen with tortuous retinal arterioles and peripapillary telangiectases; ${ }^{12}$ optic atrophy is apparent within 2 months. The visual field loss progresses from an enlarged blind spot to a large centrocaecal scotoma. Loss of visual acuity is generally severe $\left(6 / 60\right.$ or less). ${ }^{13}$

About $85 \%$ of patients with Leber's optic atrophy are male, and $18 \%$ of female carriers are affected. Paternal transmission of the disease to children or grandchildren has never been described, making $\mathrm{X}$ linked inheritance unlikely. Between 70 and $100 \%$ of daughters of female carriers are also carriers, and 50 to $100 \%$ of the sons of carriers are affected. This pattern of transmission suggests cytoplasmic or mitochondrial inheritance. ${ }^{4-8}$

On the basis of these observations, and also because of the finding of enlarged mitochondria with proliferation of cristae in skeletal muscle biopsies from patients, Nikoskelainen and colleagues ${ }^{49}$ have suggested that Leber's optic atrophy may be a mitochondrial disease, caused by mutations of mitochondrial (mt) DNA. Human mt DNA is a closed circular molecule 16,569 base pairs in length. ${ }^{10}$ It is exclusively maternally transmitted, ${ }^{11}$ and codes for two ribosomal RNAs, 22 tRNAs, and 13 subunits of the mitochondrial oxidative phosphorylation system. ${ }^{12-14} \mathrm{~A}$ number of restriction fragment length polymorphisms have been demonstrated in mt DNA Address for reprint requests: Dr A E Harding, University Department of Clinical Neurology, Institute of Neurology, Queen Square, London WCIN 3BG, UK.

Received 14 January 1988 and in revised form 21 April 1988. Accepted 26 April 1988 from different maternal lines. ${ }^{15}$ In order to test the hypothesis that Leber's optic atrophy is caused by defects of the mitochondrial genome, we have studied mt DNA restriction fragment patterns from affected and unaffected members of Leber's optic atrophy families and control subjects.

\section{Patients and methods}

1 Patients We investigated three groups of cases: (1) 16 patients (14 males and two females) with Leber's optic atrophy from 10 families; (2) 28 unaffected matroclinal relatives from these families, including three obligate carrier females (with two affected sons or an affected son and brother or nephew), 14 males at risk of being affected by virtue of having affected brothers or cousins and being under the age of 30 years, and 11 females who were potentially carriers (that is, with one affected son or affected brothers/nephews); and (3) 35 normal control subjects who were also used in a similar study of mitochondrial myopathy. ${ }^{16}$

Leber's optic atrophy was diagnosed using the following criteria: (a) subacute bilateral visual failure developed between the ages of 15 and 40 years; (b) examination in the early phase of the illness showed bilateral centrocaecal scotomata and characteristic fundal changes (disc swelling, peripapillary telangiectasia); (c) other causes of optic neuropathy were excluded; and (d) there was a family history of a similar disorder without paternal transmission. The first three criteria were fulfilled in all 16 cases, and 14 had affected relatives. The two females both had affected brothers.

2 Methods DNA was extracted from $20 \mathrm{ml}$ blood from each subject using standard methods. ${ }^{17}$ Samples of DNA $(5-10 \mu \mathrm{g})$ were digested with $10 \mathrm{u}$ each of 28 restriction endonucleases under conditions recommended by the manufacturers (Bethesda Research Laboratories and Northumbria Biologicals Limited), with the addition of bovine serum albumin $(0 \cdot 1 \mathrm{mg} / \mathrm{ml})$ and spermidine $(10 \mathrm{mM})$. 
The digested DNA fragments were separated by horizontal agarose gel $(0 \cdot 8 \%-1 \cdot 8 \%)$ electrophoresis for $6-16$ hours at $38-110 \mathrm{~V}$ and then transferred to nylon filters (Hybond-N, Amersham, UK) by the method of Southern. ${ }^{18}$

Purified HeLa cell mt DNA was labelled with ${ }^{32} \mathrm{P}$ by nick translation $^{19}$ and hybridised to DNA on the filters under conditions recommended by Amersham for Hybond-N. Fragments of mt DNA were visualised by autoradiography for $24-48$ hours at $-70^{\circ} \mathrm{C}$.

\section{Results}

No deviation in the cleavage pattern expected from the published sequence of $\mathrm{mt} \mathrm{DNA}^{10}$ was seen with 12 of the 28 restriction endonucleases $(\mathrm{Bg} / \mathrm{I}$, Bst EII, EcoRI, EcoRV, Hind III, Hae III, Hpa I, Kpn I, Pst I, Rsa I, Xba I, Xho I). All the Hinc II digests gave the pattern observed in most Caucasians. ${ }^{20}$ With the other restriction endonucleases (Ava I, Ava II, Bam HI, Bcl I, Cfo I, Dra I, EcoR II, EcoRV, Hae II, Msp I, Nde I, Sac I, Sca I, Stu I, Taq I), previously reported mt DNA polymorphisms ${ }^{111621-25}$ were seen in $11 / 16$ patients (from eight families), all 24 of their matroclinal relatives, and 20/35 controls. One previously unreported polymorphism was seen in a male with Leber's optic atrophy and his unaffected sister. This polymorphism has also been found subsequently in a normal subject not used as a control in this study. Pvu II produced two fragments of around 13.5 and $3.0 \mathrm{~kb}$ instead of the expected $16.5 \mathrm{~kb}$ fragment.

No variation in restriction endonuclease cleavage patterns was seen between affected and unaffected individuals in any single maternal line. There was no evidence of major deletion of mt DNA in patients.

\section{Discussion}

This study showed no mt DNA restriction fragment length polymorphism unique to patients with Leber's optic atrophy with the 28 restriction endonucleases used. An estimated $10 \%$ of the mitochondrial genome has been screened for site gains and losses with these enzymes. A major deletion of leukocyte/platelet $\mathrm{mt}$ DNA ( $>50 \mathrm{bp}$ ) can be excluded but small deletions or single nucleotide changes cannot. A similar study of mt DNA in an unusual family, in which Leber's optic atrophy was seen in some members and maternally inherited dystonia in others, was also negative. ${ }^{26}$

Despite the fact that Leber's optic atrophy appears to be maternally transmitted, it is difficult to understand how this disease could be caused by mutations of mt DNA, given that mt DNA codes exclusively for subunits of the mitochondrial respiratory chain and oxidative phosphorylation system. The other group of disorders which may be maternally inherited is the mitochondrial myopathies. ${ }^{27}$ Their clinical features are very variable. Visual failure due to optic neu- ropathy is relatively rare and only slowly progressive. ${ }^{28}$

In vitro studies of mitochondrial metabolism in patients with mitochondrial myopathy usually show defects of the mitochondrial respiratory chain ${ }^{28-30}$ which could result from abnormal mt DNA encoded products, ${ }^{12-14}$ so the mitochondrial myopathies are rather stronger candidates for pathological alterations of the mitochondrial genome than Leber's optic atrophy. Multiple restriction endonuclease analysis of leukocyte mt DNA in patients with defects of the respiratory chain has also failed to show any positive evidence of mutation of mt DNA. ${ }^{163031}$ However, Holt et $\mathbf{~}^{32}$ have recently shown that nine of 25 patients with mitochondrial myopathy had two populations of mt DNA in muscle, one of which was deleted by up to $7 \mathrm{~kb}$, as compared with a single normal population in blood. These observations suggest that heteroplasmy for mt DNA between tissues can occur in man, and that defects of the mitochondrial genome may be restricted to tissues in which they are expressed. Thus the finding of normal leukocyte mt DNA in patients with Leber's optic atrophy does not exclude the possibility of mitochondrial inheritance, but it would be difficult to examine relevant tissue for mt DNA heteroplasmy in this disease.

There have been two reports of reduced rhodanese activity, in liver and rectal mucosa, in Leber's optic atrophy ${ }^{33} 34$ although others have reported normal activity in liver, brain, ${ }^{35}$ and muscle. ${ }^{9}$ Rhodanese is a ubiquitous enzyme which may play a role in the formation of iron sulphur proteins, important molecules in electron transfer, ${ }^{36}{ }^{37}$ which is of interest in relation to the hypothesis that the molecular basis of Leber's disease is one which would predictably be associated with defects of the mitochondrial respiratory chain. Intriguingly, $\operatorname{Roger}^{38}$ has recently reported a patient with the syndrome of myoclonus epilepsy with ragged red fibres who also has "typical Leber's disease".

We thank Professor W I McDonald for allowing us to study his patients, Dr C J Poole for supplying some of the blood samples, Dr G Attardi for the gift of purified HeLa cell mitochondrial DNA, and the Brain Research Trust for financial support.

\section{References}

1 Nikoskelainen E, Hoyt WF, Nummelin K. Ophthalmoscopic findings in Leber's hereditary optic neuropathy. The fundus findings in the affected family members. Arch Ophthalmol 1983;101:1059-68.

2 Nikoskelainen E. Hoyt WF. Nummelin K. Ophthalmoscopic findings in Leber's hereditary optic neuropathy. Fundus findings in asymptomatic family members. Arch Ophthalmol 1982;100:1597-602.

3 Carroll WM, Mastaglia FL. Leber’s optic neuropathy: a clinical 
and visual evoked potential study of affected and asymptomatic members of a six generation family. Brain 1979; 102:559-80.

4 Nikoskelainen E, Savontaus ML, Wanne OP, Katila MJ, Nummelin K. Leber's hereditary optic neuroretinopathy, a maternally inherited disease. Arch Ophthalmol 1987;105:665-71.

5 Seedorf T. Leber's disease. Acta Ophthalmol 1970;48:187-213.

6 Wallace DC. Leber's optic atrophy: a possible example of vertical transmission of a slow virus in man. Austr Ann Med 1970:3:259-62.

7 Erickson RP. Leber's optic atrophy: a possible example of mitochondrial inheritance. Am J Hum Genet 1972;24:348-9.

8 Nikoskelainen E. New aspects of the genetic, etiologic and clinical puzzle of Leber's disease. Neurology 1984:34:1482-4.

9 Nikoskelainen EK, Hassinen IE, Paljarvi L, Lang H, Kalimo H. Leber's hereditary optic neuroretinopathy, a mitochondrial disease? Lancet 1984;ii:1474.

10 Anderson S. Bankier AT, Barrell BG, et al. Sequence and organisation of the human mitochondrial genome. Nature 1981:290:457-65.

11 Giles RE, Blanc H, Cann HM, Wallace DC. Maternal inheritance of human mitochondrial DNA. Proc Natl Acad Sci USA 1980:77:6715-19.

12 Yatscoff RW. Goldskin S. Freedman KB. Conservation of genes coding for proteins synthesised in human mitochondria. Somat Cell Genet 1978:4:633-45.

13 Chomyn A, Mariottini P. Cleeter MWJ, et al. Six unidentified reading frames of human mitochondrial DNA encode components of the respiratory chain NADH dehydrogenase. Nature 1985;314:592-7.

14 Chomyn A, Mariottini P, Cleeter MWJ, et al. Functional assignment of the unidentified reading frames of human mitochondrial DNA. In: Quagliariello E, Slater EC. Palmieri F. Saccone C. Kroon AM, eds. Achievements and Perspectives of Mitochondrial Research, vol. II: Biogenesis. Amsterdam: Elsevier, 1985:259-75.

15 Cann RL. Stoneking M. Wilson AC. Mitochondrial DNA and human evolution. Nature 1987:325:31-36.

16 Holt IJ, Harding AE, Morgan-Hughes JA. Mitochondrial DNA polymorphism in mitochondrial myopathy. Hum Genet 1988:79:53-7.

17 Old JM. Fetal DNA analysis. In: Davies KE. ed. Human Genetic Diseases: a Practical Approach. Oxford: IRL Press 1986:1-17.

18 Southern EM. Detection of specific sequences among DNA fragments separated by gel electrophoresis. J Mol Biol 1975: 98:503-17.

19 Rigby PWJ, Diekmann M. Rhodes C. Berg P. Labelling DNA to high specific activity in vitro by nick translation with DNA polymerase 1. J Mol Biol 1977:113:237-51.

20 Blanc H. Chen K. d'Amour MA. Wallace DC. Amino acid change associated with the major polymorphic Hinc II site of oriental and Caucasian mitochondrial DNAs. Am J Hum Genet 1983;35:167-76.

21 Johnson MJ, Wallace DC, Gerris SD, Rattazzi M, Cavalli-Sforza LL. Radiation of human mitochondrial DNA types analysed by restriction endonuclease cleavage patterns. J Mol Evol 1983;19:255-71.

22 Bonne-Tamir B, Johnson MJ, Natali A, Wallace DC, CavalliSforza LL. Human mitochondrial DNA types in two Israeli populations. A comparative study at the DNA level. Am J Hum Genet 1986;38:341-51.

23 Brown WM. Polymorphism in mitochondrial DNA of humans as revealed by restriction endonuclease analysis. Proc Natl Acad Sci USA 1980;77:3605-9.

24 Horai S, Matsunaga E. Mitochondrial DNA polymorphism in Japanese II. Analysis with restriction enzymes of four or five base pair recognition. Hum Genet 1986;72:105-17.

25 Horai S, Gojobori T, Matsunaga E. Mitochondrial DNA polymorphism in Japanese I. Analysis with restriction enzymes of six base pair recognition. Hum Genet 1984;68:324-32.

26 Novotny EJ, Singh G, Wallace DC, et al. Leber's disease and dystonia: a mitochondrial disease. Neurology 1986;36:1053-60.

27 Egger J, Wilson J. Mitochondrial inheritance in a mitochondrially mediated disease. $N$ Eng $J$ Med 1983;309:142-6.

28 Petty RKH, Harding AE, Morgan-Hughes JA. The clinical features of mitochondrial myopathy. Brain 1986;109:915-38.

29 DiMauro S, Bonilla E, Zeviani M, Nakagawa M, DeVivo DC. Mitochondrial myopathies. Ann Neurol 1985;17:521-38.

30 Morgan-Hughes JA, Hayes DJ, Cooper M, Clark JB. Mitochondrial myopathies: deficiencies localised to complex I and complex III of the respiratory chain. Biochem Soc Trans 1985:13:648-50.

31 Poulton J, Turnbull DM, Mehta AB, Wilson J, Gardiner RM Restriction enzyme analysis of the mitochondrial genome in mitochondrial myopathy. $J$ Med Genet (in press).

32 Holt IJ, Harding AE. Morgan-Hughes JA. Deletions of muscle mitochondrial DNA in patients with mitochondrial myopathies. Nature 1988:331:717-9.

33 Cagianut B, Rhyner K, Furrer W, Schnebli HP. Thiosulphatesulphur transferase (rhodanese) deficiency in Leber's hereditary optic atrophy. Lancet 1981:ii:981-2.

34 Poole CJ. Kind PRN. Deficiency of thiosulphate sulphurtransferase (rhodanese) in Leber's hereditary optic neuropathy. Br Med J 1986;292:1229-30.

35 Wilson J. Leber's hereditary optic atrophy: a possible defect of cyanide metabolism. $J$ Neurol $S c i$ 1965:29:505-15.

36 Cerletti P. Seeking a better job for an underemployed enzyme: rhodanese. Trends Bioch $S c i$ 1986:11:369-72.

37 Hatefi $Y$. The mitochondrial electron transport and oxidative phosphorylation system. Ann Rev Biochem 1985:54:1015-69.

38 Roger J. Genetic transmission of myoclonus epilepsy with ragged red fibers. Ann Neurol 1986:20:545. 